\title{
FEATURES OF CRIMINAL LIABILITY OF A MEDICAL PROFESSIONAL FOR FAILURE TO PERFORM OR IMPROPER PERFORMANCE OF THEIR PROFESSIONAL DUTIES IN UKRAINE
}

10.36740/WLek202011138

\author{
Olha S. Bondarenko, Oleg M. Reznik, Mykhailo O. Dumchikov, Nadiia S. Horobets \\ SUMY STATE UNIVERSITY, SUMY, UKRAINE
}

\begin{abstract}
The aim: Research of features of criminal responsibility of the medical worker for failure to performe or imptoter perfomance of their professional duties in Ukraine. Materials and methods: The article uses general scientific and special scientific methods of cognition, which provided an objective analysis of the research goal. Conclusions: Criminal law, which provides for liability for improper performance of duties by a healthcare professional or pharmacist, must have a perfect design to ensure the rights and interests of both the patient and the medical worker.That is why, the existing construction of article 140 of the Criminal code of Ukraine requires a number of changes and additions.
\end{abstract}

KEY WORDS: medical worker, professional responsibilities, patient, minor, serious consequences

Wiad Lek. 2020;73(11):2549-2554

\section{INTRODUCTION}

Now the society has passed the centuries-old development is at the stage of the information society. Many standards, norms and principles relating to human rights and their significance have now been developed and implemented. Today the problem of ensuring human rights is not just national, but international. Many international, governmental and public organizations have been created in the world, whose activities are aimed at ensuring and implementing human and civil rights and freedoms. The universal Declaration of human rights is the main document that enshrines the right to life and medical care that is necessary to maintain her health [1].

In democratic countries, human life and health are recognized as the highest social value [2, p. 2402]. Ukraine, as part of the international community, enshrines and details these provisions in its domestic legislation. Thus, according to the Basic Law, Ukraine is a legal state where a person, his life and health, honor and dignity, inviolability and security are recognized as the highest value,. According to this list, human life and health are the main objects for protection in the state. This provision is specified in many articles of the Constitution of Ukraine. In particular, article 27 enshrines the right to life, and article 49 of the Constitution establishes the right to health protection and medical care. The state creates conditions for effective and accessible medical care for all citizens [3].

The priority nature of these constitutional provisions is enshrined in many legal acts. The key of effective guarantee, implementation and expression of priority value is the criminal legal protection of certain public relations. Current practice proves the fact that there is obvious complex

interconnection between medicine and law. Having long-lasting history of their establishment along with the contemporary high-profile sensitive cases, as well as the significant amount of various scientific researches clearly reflects that the issue of their correlation certainly remains a focus of public attention, especially when it comes to medical professionals, their actions and liability [4, p. 2573]. Moreover, the structure of the special part of the Criminal code of Ukraine is developed in accordance with the role of objects of protection for society. The second section of the Special part of the criminal law of Ukraine "Crimes against life and health". All crimes in this section are aimed to punish those who infringe on the basic natural rights of a person. A number of them establish criminal liability for medical workers as special subjects whose activities are specifically aimed at maintaining or restoring human life. The current criminal law contains a number of articles the subjects of which are medical workers, in particular, improper performance of professional duties by a medical worker, which resulted in infection of a person with the human immunodeficiency virus or other incurable infectious disease (article 131 of the Criminal code of Ukraine); disclosure of employee medical information, medical examinations to identify infection with the human immunodeficiency virus or other incurable infectious diseases (article 132 of the Criminal code); unlawful abortion or sterilization (article 134 of the Criminal code of Ukraine); failure to assist a patient health worker (article 139 of the Criminal code); improper execution of 
professional duties by medical or pharmaceutical workers (article 140 of the Criminal code); violation of the rights of the patient (article 141 of the Criminal code of Ukraine); illegal conduct of experiments on a person (article 142 of the criminal code); forced donation (article 144 of the Criminal code of Ukraine); illegal disclosure of medical secrets (article 145 of the Criminal code of Ukraine). We would like to focus special attention on the study of the features of bringing a medical professional to responsibility for improper performance of professional duties and distinguishing this criminal act from related ones. After all, the construction of this legal norm must meet a number of requirements. At first to protect patients from arbitrariness or inaction of medical workers. At second to protect medical workers themselves from unfounded accusations.

\section{ANALYSIS OF RECENT RESEARCH AND PUBLICATIONS}

Many autors reserched features of criminal responsibility of the medical worker for failure to performe or imptoter perfomance of their professional duties. For example, L. Schwartz, O. Paramonova, I. Fil, L. Karpenko, J. Marcelin and many others. However, there is no comprehensive scientific study of the analyzed crime, which would take into account all changes in the legislation.

\section{THE AIM}

The aim of the article is providing characteristics of criminal liability of the health care professional for failure to performe or imptoter perfomance of their professional duties.

\section{MATERIALS AND METHODS}

In this article, the authors used both general scientific and specially scientific methods. In view of the topic, purpose and objectives of the study, a dialectical method was used to interpret the conceptual and categorical apparatus of the research; the method of scientific analysis and synthesis has been used to investigate the constituent elements and features of the composition of the crime failure to performe or imptoter perfomance of their professional duties by medical worker; the formal and legal method is used to analyze the current legislation on liability for the analyzed crime. The authors also used a system-structural method that allowed them to analyze all the concepts systematically (in relation to and interconnected with other legal concepts). These and other research methods were used in this research in interconnectedness and interdependence, which ensured the comprehensiveness and completeness of the research, the truth of the obtained scientific results.

\section{REVIEW AND DISCUSSION}

Analyzing official statistics, it was found that the most common crime that is committed by medical workers is an improper performance of professional duties by a medical or pharmaceutical worker. So, in 2018,99 criminal proceedings were registered, and in 2019 - 130 [5]. Moreover, we are convinced that given the high latency of all crimes committed by special subjects and the level of their concealment by other colleagues, the official statistics are significantly different from the real ones. The upward trend is driven by many factors, both subjective and objective [ 6 , p. 877]. After all, there is no single concept of medical error; medical personnel are prosecuted only if they made an unjustified error in the presence of all mandatory elements of the crime under the relevant article of the Criminal Code of Ukraine. At the same time, it is extremely difficult to prove the existence of such an error. In addition, at the state level, the causes and mechanisms of errors are not identified, they are not even discussed, which makes it impossible to outline measures to prevent them or reduce the frequency and degree of danger. In addition, there is no clear legislation in Ukraine that would explain what should be considered improper performance of professional duties, the rights and obligations of specific medical workers are very blurred in places, and the necessary equipment and drugs to provide qualified care are often not available on the ground. Moreover, the level of material support for doctors remains unsatisfactory. At the same time, there is another problem: law enforcement agencies are required to register all reports of a crime within 24 hours of their receipt. However, both often patients themselves and their relatives because of the image, misperception of the situation, or due to a biased attitude towards a particular doctor or the profession of doctor in general don't interprete his methods of diagnosis and treatment properly. This leads to the unjustified statements and messages on Commission of crime, which later areclosed for the lack of evidence [7, p. 39].

According to article 2 of the Criminal code of Ukraine, the only basis for criminal liability of a person is the commission of a socially dangerous act that contains the elements of a crime provided for in this Code. Unfortunately, the level of legal culture and legal awareness in Ukraine, both among medical professionals and the entire population, is at a very low level. That is why the vast majority of medical professionals have only a superficial idea of the legal liability that is established by current legislation for violations in the field of health protection. At the same time, knowledge of the grounds, types and consequences of legal liability, on the one hand, disciplines medical professionals, and on the other - reduces the likelihood of unjustified prosecution of them [8].

It is advisable to analyze the composition of each crime through the prism of its objective and subjective features. And the first of them is the object of the crime, that is, those social relations that were harmed or threatened by the crime. The analyzed crime has two objects of encroachment. The first of them (the main one) is human life (the right to life is a fundamental, inalienable, absolute human right, which means that the state guarantees protection from attacks on life and deprivation of life, maintenance of life and promotion of its extension) [9, p. 20] and human 
health (a state of complete physical, mental and social well-being, and not only the absence of diseases and physical disabilities) [10].

The additional object of the crime is the established procedure for performing medical and pharmaceutical workers ' professional duties. To clarify the essence of the concept of "procedure for medical and pharmaceutical workers to perform their professional duties", it is important to note that Ukraine is currently in a state of significant reforms in the medical industry, when new approaches to the capacity of medical workers and the boundaries of their delinquency are just emerging and beginning to develop. That is why it is now important to introduce an effective mechanism that could protect both the rights of patients and clearly and objectively outline the cases of responsibility of medical professionals. After all, the existing wording gives grounds to regard any violations as criminal. In addition, O. Paramonova believes that the essence of this crime is the wrong illegal performance of medical and pharmaceutical workers of their professional duties. Therefore, the direct object of the act can be defined as public relations that ensure the right of citizens to qualified medical care [11, p. 246].

The victim is also singled outin the structure of the object of crime.The victim is a patient in this crime. A significant drawback of this article is the use of the very concept of "sick person" while most legal acts, given that medical care is also considered as a type of public service, use the term "patient". Such terminological differences are absolutely unacceptable in the field of criminal, the strictest legal liability, and in practice can lead to different law enforcement, which negates both the main international and domestic legal bases. We are convinced that the unification of concepts is a priority for the legislator. We consider it is necessary to use the term "patient" - an individual who has applied for medical assistance and / or who is receiving such assistance [10].

In addition, the victim of a crime under part 2 of article 140 of the Criminal code of Ukraine is a minor. Despite the fact that according to the Civil code of Ukraine, a minor is a person between the ages of 14 and 18, in this article it is still necessary to use not a literal, but an extended interpretation, and the victim may be a person under 18 years of age.On the objective side, the crime provided for in article 140 of the Criminal code of Ukraine is characterized by two acts, socially significant consequences and a causal relationship between the acts and the consequences. The first act is a failure to perform professional duties. By and large, non-compliance predictsthat a person does not perform the duties assigned to him, although he should have and could. The second action is improper execution, that is, although the person performs certain actions, but implements them superficially, not in full [12, p. 85].

Since the disposition of the article under investigation has a blank character, it should be established which professional duties were assigned to the medical worker and which of these duties were not performed at all or were not performed properlyin each specific case, as well as the requirements of which specific regulations (instructions, rules, instructions)were initiated by the suspect. It should be borne in mind that the diagnosis and the choice of a particular method and method of treatment depend on many factors. In particular, the individual characteristics of the patient's body, the achievements of medical science and experience of therapeutic activity. Therefore, they cannot be fully regulated in advance by health regulations $[13$, p. 70$]$.

Regarding the consequences of the investigated action, the legislator clearly indicates that they should be severe. At the same time, the concept of "grave consequences" is estimated and will be determined by the court independently in each specific case. Thus, from the analysis of judicial practice, it follows that they traditionally recognize several types of consequences. First, bodily injury is a violation of the anatomical integrity of tissues, organs and their functions that occurs as a result of the action of one or more external damaging factors -physical, chemical, biological, and mental. According to the rules of forensic medical determination of the severity of injuries in the case of improper medical care, which resulted in a violation of the anatomical integrity of tissues and organs and their functions, the expert Commission has the right to consider this violation as a bodily injury and determine its severity By the rules of forensic medical determination of the severity of injuries [14, p. 78].

In Ukraine, injuries are: mild, moderate and severe. If we analyze the sanctions of the articles that stipulate the general conditions of liability for each of these types of injuries, they are more severe. In our view, this legislative approach is quite balanced, since; first and foremost, health care providers are a specific category that the state is obliged to provide qualified health care. At the same time, any person in any sphere of life is not protected from mistakes. Secondly, the fault of the medical worker before the act was committed is not intentional, but especially with regard to the consequences.

Secondly, the consequences of committing a crime under article 140 of the Criminal code of Ukraine may be the death of the victim caused by inaction or careless actions of a medical professional. Third, bringing the victim to suicide. For example, the perpetrator (the doctor) informed the patient that he was suffering from an incurable disease and, without wishing to do so, caused a mental health disorder, which led to suicide. The peculiarity of this feature of the crime is that it contains two socially dangerous consequences: the primary-a mental health disorder of the victim and the derivative-death. Suicide in the General psychological aspect is understood as human behavior aimed at self-destruction. The result of suicide is the biological death of a person. The subject of the crime treats both consequences carelessly [11, p. 188].

In the context of the amendment of the text of the disposition of the article of Art. 140 of the Criminal Code of Ukraine it seems appropriate to replace the phrase «severe consequences» with «severe consequences for the patient's health», which will help to better understand the meaning 
of negative consequences that lead to legal liability for improper performance of professional duties by a medical or pharmaceutical worker, and will help to exclude from the content of this article all those consequences which do not concern life and health of the patient [15, p. 10].

Since the performance of professional duties is in most cases a certain process, it is important to establish the time of the end of this crime. The act provided for in article 140 of the Criminal code of Ukraine is formulated in the law as a crime with material composition. With regard to this issue, this means that one or another form of therapeutic effect acquires all the features of the objective side of the act provided for in article 140 of the Criminal code of Ukraine, only from the moment when the failure or improper performance of professional duties by a medical or pharmaceutical employee is manifested in a negative result, described in the law by the term "grave consequences for the patient [16, p. 297].

The subject of the crime is special, that is, a medical or pharmaceutical employee. The definition of the term "medical worker" is contained in the Ethical code of a doctor of Ukraine. At the same time it is completely wrong to identify a medical professional with a doctor [17, p. 199].

We are convinced that such a subject can be personswho have special education and meet the Uniform qualification requirements established by the Ministry of health for persons engaged in certain types of medical and pharmaceutical activities, including in the field of folk and alternative medicine [16, p. 299]. It should also be noted that the qualification is not affected by the form of the ownership to which belongs the hospital, where non-medical care is provided: public, municipal or private property. For a person to be recognized as the subject of this crime, he or she must meet not only General criteria: an individual, sanity, reaching a certain age, but also meet a number of special ones. The first of them is the availability of special medical education. The procedure for obtaining medical education, especially with regard to higher medical education, differs significantly from the procedure for obtaining education in other areas and specialties. The requirements and level of responsibility for this profession give rise to the increased selection criteria for training (increased level of results of external independent evaluation in specialized subjects); increased duration of training; training in an indivisible cycle, and so on. Thus, training, retraining and professional development of medical and pharmaceutical workers are carried out by the relevant secondary special and higher educational and scientific institutions, institutions of professional development and retraining, as well as through internships, medical residency, clinical residency, postgraduate and doctoral studies in accordance with the legislation on education [8]. That is, the qualification of the crime is not affected by what kind of secondary or higher education the medical worker has. That is, the subject of this crime can be a doctor, regardless of his profile, a nurse, or a paramedic.

We believe that when training young specialists, special attention should be paid to the formation of an unbiased and objective attitude to all patients, regardless of skin color, race, religion, sex or property qualification. Because now, numerous data about the unconscious influence of personal preferences on the process of providing care, interaction with the patient, etc. [18, p. 70]. This leads to the conclusion that a doctor can apply risky therapies in order to save a patient's life, keep an organ in function, etc., by first comparing the risky action and its potential outcome [19, p. 2411].

The second feature is compliance with the unified qualification requirements. Thus, a significant achievement is the existence of a unified State standard of higher medical and pharmaceutical education, which is the key to a unified, standardized approach to training qualified medical and pharmaceutical workers. Moreover, despite the fact that this standard is approved by the Ministry of Education and Science, but with the assistance and coordination of the Ministry of Health. This fact reaffirms that the standard meets the practical requirements of the profession and provides not only the preparation of general theoretical competences, but also specific practical skills.

The third sign is the presence of a special permit or license certifying the right to practice medical activities. A permit is required for those medical or pharmaceutical workers who have received education abroad, but a license is required in the case of medical activities by individuals who are business entities [20, p. 327].

In addition, the subject of this crime is persons engaged in alternative medicine, that is, healers (individuals-entrepreneurs who are engaged in folk medicine (healing) and received a special permit to practice folk medicine (healing) in accordance with the law to provide medical care to patients using traditional medicine methods based on the experience of many generations of people, established in folk traditions and do not require state registration) [21].

The last element of the composition of the investigated crime is its subjective side, which is characterized by a careless form of guilt, both criminal negligence and criminal self-confidence. In particular, carelessness can be expressed here in the form of criminal arrogance, in which a person foresees the possibility of the occurrence of socially dangerous consequences of their activities, but frivolously expects to prevent them. Frivolous calculation is usually based on the presence of certain professional abilities, skills, and experience in treatment. In the case of criminal arrogance, the determination of a person to perform actions to achieve the goal is connected with the calculation to prevent the occurrence of socially dangerous consequences. The guilty person may also fail to foresee the occurrence of socially dangerous consequences of their activities, mistakenly believing that they are unable to cause a socially dangerous result. In this case, the careless form of guilt manifests itself in the form of criminal negligence [16, p. 298].

In the context of the correct qualification of the acts of the person it is important to take into account the delimitation and abcence of the assistance to the patient by the medical officer, (article 139 of the Criminal code of Ukraine) medical or pharmaceutical workers (article 140 
of the Criminal code of Ukraine). In our opinion, these articles are inconsistent with each other, because they are extremely similar. The only sign that allows them to differentiate is the form of guilt, so for article 139 of the Criminal code of Ukraine it is intentional, and for article 140 of the Criminal code of Ukraine-careless. For this reason, the legislator should consider the expediency of the existence of two norms and the possibility of introducing one of the remoteness of deliberate and careless guilt in two parts of the same article.

With regard to the punishment for committing a crime under Article 140 of the Criminal Code of Ukraine, we analyzed 65 court decisions included in the Unified State Register of Court Decisions of Ukraine for the period from 2011 to June 2020, according to which 67 medical workers were charged with crimes, under Art. 140 of the Criminal Code of Ukraine. Of these health workers, the majority (36 doctors and 3 nurses) were found not guilty and acquitted, and only 26 were found guilty by a court. However, only 10 persons were sentenced to actual punishment: 3 to imprisonment, 4 to restriction of liberty, and 3 to a fine. An additional penalty of deprivation of the right to engage in medical activities was imposed on 8 persons. Out of 10 convicts, only 2 were sentenced to more than 2 years in prison. Instead, most people were simply released from prison [22]. For example, one of the sentences on the accusation of a doctor under Part 1 of Art. 140 of the Criminal Code of Ukraine was acquittal (case /2018 / 1-47 / 11). The court ruled that the pre-trial investigation authorities had not proved, and the court session had not established, that during the victim's treatment there were circumstances that gave grounds to believe that the defendant had a thrombosis disorder, which subsequently led to her death. .Thus, the defendants met the requirements for the treatment of the patient, with the exception of certain laboratory tests, the absence of which could not affect the course of injury [23]. Instead, in another case (case № 106/11825/2012), the defendant, after conducting an initial examination of the victim, underestimated the severity of the traumatic factor (falling from a height of 4 floors), the severity of injuries and the severity of the general condition of the victim. Defects found in the victim's ribs and pelvic bones, the defendant mistakenly regarded as "outdated". Neurological disorders are mistaken for manifestations of cerebral atherosclerosis. In order to clarify the diagnosis, the doctor did not give instructions to medical staff for emergency catheterization of the bladder, electrocardiogram, not called for consultation neurosurgeon (neurologist). Underestimating the severity of the patient's condition, the doctor did not take the necessary measures to treat the patient, namely: immediate transfer of the victim to the shock room or intensive care unit with immediate initiation of infusion-transfusion therapy and other anti-shock measures. It should also be noted as a wrong referral of the patient for radiography, due to the fact that additional transportation and transfer could aggravate the patient's condition. These actions were qualified by the court under Article 140 of the Criminal Code of Ukraine - non-performance or improper performance by a medical or pharmaceutical worker of their professional duties due to negligent or dishonest treatment [24]. Thus, the judicial practice of Ukraine follows the path of imposing a medical negligence penalty in the form of imprisonment only in extreme, exceptional cases, mainly limiting it to milder measures of influence or even freeing such persons from serving their sentences [26, p. 2164].

Analyzing the judgments against Ukraine rendered by the European Court of Human Rights, it can be noted that the court continues to record the constant non-compliance of the Ukrainian authorities with patients' rights. In the decisions of the European Court of Human Rights in the cases «Kushnir v. Ukraine» (2014), «Temchenko v. Ukraine» (2015), «Savinov v. Ukraine» (2015), «Serhiy Antonov v. Ukraine» (2015), «Yaroshovets and others v. Ukraine» (2015), «Korneykova and Korneykov v. Ukraine» (2016), «Barsukov v. Russia» (2017) and others, improper performance of professional duties by medical or a pharmaceutical worker is recognized as inhuman and degrading treatment within the meaning of Art. 3 of the Convention for the Protection of Human Rights and Fundamental Freedoms [26].

In particular, in case Barilo v. Ukraine (application no. 9607/06) the applicant, who was suspected of having committed an official crime, had the status of a disabled person of group 3, suffered from diabetes mellitus and others chronic diseases. The applicant was in constant need of insulin injections, a special diet and constant medical supervision, which could not be provided in places of detention. Despite these arguments, the applicant was placed by the authorities at the Saki ITT for 10 days. According to the applicant, between 12 and 16 February 2006 she had injected herself with insulin because the ITT paramedic was on leave and the ambulance refused to come to the ITT. Immediately after her release, the applicant was hospitalized at the Evpatoria City Hospital, where she was diagnosed with diabetes mellitus, severe and suspected of having diabetic precoma (a condition preceding diabetic coma). Her health has deteriorated significantly.The court found that the applicant had not been provided with adequate medical care during her detention and that the conditions of her detention at the ITK in Saki constituted inhuman and degrading treatment. Although the applicant had been in the above conditions for only 10 days, she had suffered, which had greatly worsened her already poor health [27].

Improper performance of professional duties by a medical or pharmaceutical worker can be carried out at the general social, special criminological and individual levels. The purpose of these measures is to influence the causes and conditions of improper performance of professional duties by a medical or pharmaceutical worker, as well as to reduce the commission of this crime in the future [28, p. 17].

\section{CONCLUSIONS}

Finally, we believe that criminal law, which provides for liability for improper performance of duties by a medical or pharmaceutical worker, should have an ideal design that 
ensures the rights and interests of both the patient and the healthcare professional. Therefore, the existing structure of Article 140 of the Criminal Code of Ukraine requires a number of changes and additions. In particular, replace the concept of "sick person" with the concept of "patient"; do not equate a medical worker exclusively with a doctor.

\section{REFERENCES}

1. General Declaration of Human Rights. https://zakon.rada.gov.ua/laws...

2. Yanovska 0.H., Horodovenko V.V., Bitsai A.V. Legal mechanisms of patient's rights protection. Wiad Lek. 2019;72(12):2399-2403.

3. Constitution of Ukraine No. 254k/96-VR. dated June 28, 1996. http:// zakon3.rada.gov.ua/laws...- \%D0\%B2\%D1\%80.

4. Streltsov Y. L., Kuzmin E.E. On medical professionals and criminal liability: a dark side of good intentions. Wiad Lek. 2019;72(12):2573-2578.

5. General Prosecutor's office of Ukraine. https://old.gp.gov.ua/ua/stati...

6. Gornostay A., Ivantsova A., Mykhailichenko T. Medical Error and Liability for it in some Post-Soviet Countries.Wiad Lek, 2019;5:877-882.

7. Schwartz L. Is there an advocate in the house? The role of health care professionals in patient advocacy. Journal of Medical Ethics. 2002; 28:37-40. doi: 10.1136/jme.28.1.37

8. Letter from the Ministry of Justice of Ukraine: letter dated June 20, 2011. https://zakon.rada.gov.ua/laws....

9. Perevozchikova Ye.V. Konstitutsionnoye pravo na zhizn'i reproduktivnyye prava cheloveka [Constitutional right to life and reproduction human rights]. Kazan, 2006. 25. (in Russian).

10. Fundamentals of health care legislation: Law № 254k/96-VR. dated 19 November. 1992. http://zakon3.rada.gov.ua/ laws/show/2801-12/

11. Paramonova 0.S. Rodovyy ta bezposeredniy ob"yekty zlochynu, peredbachenoho st. 140 KK Ukrayiny [Generic and direct object of the crime under Art. 140 of the Criminal Code of Ukraine]. Current problems of state and law. 2010; 55: 243-247. (in Ukrainiane).

12. Lyzohub Y.A. Problemy kryminal'noyi vidpovidal'nosti za nenalezhne vykonannya obovyazkiv medychnym abo farmatsevtychnym pratsiavnykom (st. 140 KK Ukrayiny) [Problems of criminal liability for improper performance of duties by a medical or pharmaceutical worker (Article 140 of the Criminal Code of Ukraine)]. Law of Ukraine. 2005; 4 : 85-88. (in Ukrainiane).

13. Zadorozhko Yu.V. Osoblyvosti predmeta dokazuvannya v kryminal'nomu provadzhenni, povyazanomuz nenalezhnym vykonannya profesiynykh obovyazkv medychnym pratsivnykom (st. 140 KK Ukrayiny) [Features of the subject of evidence in criminal proceedings for improper performance of duties by a medical or pharmaceutical worker (Article 140 of the Criminal Code of Ukraine]. Scientific Bulletin of Uzhhorod National University. 2014; 28 : 69-72. (in Ukrainiane).

14. Rules of forensic determination of the severity of bodily injuries: By order of the Ministry of Health of January 17, 1995, the Criminal Code of the post. materials. 2000: 576-582. (in Ukrainiane).

15. Chernikov Ye.E. Kryminal'na vidpovidal'nist' za nenalezhne vykonannya profesiynykh pratsivnykiv medychnykh abo farmatsevtychnykh pratsivnykiv [Criminal liability for improper performance of duties by a medical or pharmaceutical worker (Article 140 of the Criminal Code of Ukraine]. Odessa State University of Internal Affairs. 2020. (in Ukrainiane).

16. Pastushenko S.S. Osoblyvosti skladu zlochynu, peredbachenoho ch. 1 st. 140 KK Ukrayiny [Features of the crime under Part 1 of Art. 140 of the Criminal Code of Ukraine]. Bulletin of the Academy of Advocacy of Ukraine. 2009; 1 (14) : 296-299. (in Ukrainiane).
17. KarpenkoL.K.Medychnyypratsivnykyakspetsial'nyysub'yektroz-holoshennya likars'koyi tayemnytsi [Medical worker as a subject of disclosure likarskoyi secrets]. Forum of law. 2014; 2: 196-202. (in Ukrainiane).

18. Marcelin J.R., Siraj D.S.,Victor R. et al. The Impact of Unconscious Bias in Healthcare: How to Recognize and Mitigate It. The Journal of Infectious Diseases. 2019; 220 (2):62-73.

19. Baulin Y.V.,PavshukK.O.,Vyshnevska I.A. Riskin the performance of medical activities: medico-legal overview. Wiad Lek. 2019;72(12):2410-2415.

20. Fil' I. M. Nadannya medychnoyi dopomohy ta vykonannya profesiynykh obovyazkiv: problemy spivvidnoshennya (v koneksti analizu statti 140 KK Ukrayiny) [Provision of medical care and performance of duties: problems of correlation (in the context of the analysis of Article 140 of the (riminal Code of Ukraine)]. Journal of Kyiv University of Law. 2009;4:325-329. (in Ukrainiane).

21. About the organization of work of physical persons-businessmen who are engaged in national medicine (healing): order Ministry of health of Ukraine № 189 dated 16 March 2016. https://zakon.rada.gov.ua/laws...

22. Register of Judicial Decisions of Ukraine. http://reyestr.court.gov.ua/Pa...

23. Register of Judicial Decisions of Ukraine. http://reyestr.court.gov.ua/Re...

24. Register of Judicial Decisions of Ukraine. http://reyestr.court.gov.ua/Re...

25. Gutorova N., Zhytnyi 0., Kahanovska T. Medical negligence subject to criminal law. Wiad Lek. 2019;72(11):2161-2166.

26. Collection of extracts from the decisions of the European Court of Human Rights. http://www.nsj.gov.ua/files/15...\%

27. Case Barilo v. Ukraine (application no. 9607/06). https://mvs.gov.ua/ upload/file...

28. Fil' I. Kryminal'no-pravova ta kryminolohichna protydiya nenalezhnomu vykonannyu profesiynykh obov'yazkiv medychnym abo farmatsevtychnym pratsivnykom [Criminal legal and criminological counterfeiting of incompetent performance of professional duties by medical or pharmaceutical workers]. NAN Ukrayiny, Institute of State and Law named after V. M. Koretsky. Kyiv. 2018: 20. (in Ukrainiane).

\section{ORCID and contributionship:}

Olha S. Bondarenko: 0000-0002-2288-1393 B,D

Oleg M. Reznik: 0000-0003-4569-8863 ${ }^{F}$

Mykhailo O. Dumchikov: 0000-0002-4244-2419 ${ }^{A, B}$

Nadiia S. Horobets: 0000-0002-0282-2775 ${ }^{\mathrm{E}}$

\section{Conflict of interest:}

The Authors declare no conflict of interest.

\section{CORRESPONDING AUTHOR}

\section{Olha S. Bondarenko}

Sumy State University

59 Petropavlivska St., 40000 Sumy, Ukraine

tel: +380662183571

e-mail: olya.tereschenk034@gmail.com

Received: 27.04 .2020

Accepted: 09.09 .2020

A - Work concept and design, B - Data collection and analysis, C - Responsibility for statistical analysis,

D-Writing the article, $\mathbf{E}$-Critical review, $\mathbf{F}$ - Final approval of the article 